\title{
Microbiological evaluation of bristles of frequently used toothbrushes
}

Celso André Ferreira', Geovana Dagostim Savi², Ana Paula Panatto', Jaqueline da Silva Generoso², Tatiana Barichello

Introduction: Brushing teeth is probably the practice of oral hygiene most common in the world; however, inadequate use can become a risk to the population health, once they may be contaminated with various microorganisms.

Objective: The aim of this study was to evaluate the bacterial contamination on toothbrush bristles using different methodologies.

Method: We used 40 toothbrushes from healthy individuals aged 3 to 58 years. The samples were grown in test tubes containing trypticase soy broth sterile, and with the help of a tracking $0.1 \mu \mathrm{l}$ samples were placed on plates containing sheep blood agar 5\% and MacConkey agar then the samples were stored in a bacteriological incubator at $37^{\circ} \mathrm{C}$ for 24 hours for later analysis. It was counted the colony forming units and bacteria identification present in the brush.

Results: On the microbiological analysis, there was a growth of Escherichia coli, Klebsiella pneumoniae, Streptococcus pyogenes and Staphylococcus coagulase negative.

Conclusion: According to the results presented in this study, we observed a high incidence of bacterial contamination in the brushes analyzed. The most frequent microorganisms were members of the Enterobacteriaceae. The usage time of toothbrushes may be related to contamination found and, therefore, not only good hygiene ensures the reduction of microbial load, but replacing the toothbrush can also ensure individuals better oral health.

Keywords: Toothbrushing. Contamination. Oral hygiene.

${ }^{1}$ Graduation in Pharmacology.

${ }^{2} \mathrm{MSc}$ in Health Sciences, Universidade do Extremo Sul Catarinense.

${ }^{3}$ Professor of Microbiology and Clinical Parasitology in the Pharmacology Graduation course and Post-Graduation in Health Sciences, Universidade do Extremo Sul Catarinense. PhD in Biology / Biochemistry, Federal University of Rio Grande do Sul.
How to cite this article: Ferreira CA, Savi GD, Panatto AP, Generoso JS, Barichello T. Microbiological evaluation of bristles of frequently used toothbrushes. Dental Press J Orthod. 2012 July-Aug;17(4):72-6.

Submitted: December 25, 2009 - Revised and accepted: October 5, 2011

" The authors report no commercial, proprietary or financial interest in the products or companies described in this article.

Contact address: Geovana Dagostim Savi

Avenida Universitária, 1105 - Bairro Universitário - Criciúma/SP - Brazil

CEP: 88.806-000 - E-mail: geovanasavi@gmail.com 


\title{
Avaliação microbiológica das cerdas de escovas dentárias de uso frequente
}

\author{
Celso André Ferreira', Geovana Dagostim Savi ${ }^{2}$, Ana Paula Panatto', Jaqueline da Silva Generoso ${ }^{2}$, Tatiana Barichello ${ }^{3}$
}

Introdução: a escovação de dentes é, provavelmente, a prática de higiene bucal mais comumente realizada no mundo; entretanto, o acondicionamento inadequado pode se transformar em um risco para a saúde da população, uma vez que podem estar contaminadas com vários tipos de microrganismos.

Objetivo: o objetivo desse estudo foi avaliar a contaminação bacteriana de cerdas de escovas dentais através de diferentes métodos.

Métodos: foram utilizadas 40 escovas de dentes provenientes de indivíduos sadios, com idade entre 3 a 58 anos. As amostras foram semeadas em tubo de ensaio contendo caldo tripticaseína de soja (TSB) estéril e, com o auxílio de uma alça de $0,1 \mu \mathrm{l}$, as amostras foram semeadas em placas contendo ágar sangue de carneiro a $5 \%$ e ágar MacConkey. Em seguida foram armazenadas em estufa bacteriológica a $37^{\circ} \mathrm{C}$ por $24 \mathrm{hs}$ para posterior análise. Foi realizada a contagem das unidades formadora de colônias (UFC) e a identificação das bactérias presentes nas escovas.

Resultados: nas análises microbiológicas, houve crescimento de Escherichia coli, Klebsiella pneumoniae, Streptococcus pyogenes e Staphylococcus coagulase negativas.

Conclusões: de acordo com os resultados apresentados nesse trabalho, verificamos que houve alta incidência de contaminação bacteriana nas escovas analisadas. Os microrganismos com maior frequência foram membros da família Enterobacteriaceae. O tempo de uso das escovas dentárias pode estar relacionado à contaminação encontrada e, por isso, não só uma boa higienização garantirá a redução da carga microbiana, mas a troca da escova dentária também pode garantir melhor saúde bucal aos indivíduos.

Palavras-chave: Escovação dentária. Contaminação. Higiene bucal.

${ }^{1}$ Graduação em Farmácia, Universidade do Extremo Sul Catarinense.

${ }^{2}$ Mestre em Ciências da Saúde, Universidade do Extremo Sul Catarinense.

${ }^{3}$ Professora da disciplina de Microbiologia e Parasitologia Clínica do curso de Farmácia e do curso de Pós-Graduação em Ciências da Saúde, Universidade do Extremo Sul Catarinense. Doutora em Ciências Biológicas/Bioquímica, Universidade Federal do Rio Grande do Sul.
Como citar este artigo: Ferreira CA, Savi GD, Panatto AP, Generoso JS, Barichello T. Microbiological evaluation of bristles of frequently used toothbrushes. Dental Press J Orthod. 2012 July-Aug;17(4):72-6.

Enviado em: 25 de dezembro de 2009 - Revisado e aceito: 5 de outubro de 2011

» Os autores declaram não ter interesses associativos, comerciais, de propriedade ou financeiros, que representem conflito de interesse nos produtos e companhias descritos nesse artigo.

Endereço para correspondência: Geovana Dagostim Savi Avenida Universitária, 1105 - Bairro Universitário - Criciúma/SP

CEP: 88.806-000 - E-mail: geovanasavi@gmail.com 


\section{INTRODUCTION}

One of the biggest public health problems of most developing countries concerns the reduction or elimination of periodontal disease and caries, even with significant prevalence in the population, related indirectly to factors such as financial, housing, culture level and eating habits. ${ }^{1}$ The toothbrush is the only instrument that the majority of the population has to control the dental biofilm ${ }^{2}$. Brushing is probably the oral hygiene practice most commonly performed in the world. The first brushes were made of pig fur and bristles made of horse mane or tail mounted in bovine bone or ivory. ${ }^{3}$ This tool has as main function the reduction of dental plaque that may be responsible for oral diseases including dental caries, periodontal disease and halitosis. ${ }^{13}$ Toothbrushes must present minimum requirements for the plaque removal such as: the bristles should be stiff enough to remove biofilm without causing trauma to the teeth and gums (optimized by rounding the active end of the bristles) and the head should be small with soft bristles. ${ }^{17}$ Another point of concern, is the fact that toothbrushes can be a source of contamination within users, ${ }^{13}$ through direct contact of different brushes from family members, or contamination from the containers that are usually moistured on the sink or in bathroom cabinets. ${ }^{6,10}$ Toothbrushes become rapidly contaminated with oral microorganisms, including bacteria, viruses and fungi. ${ }^{20}$ The oral cavity presents one of the most concentrated and varied microbial populations,notably colonized by Staphylococcus sp, Streptococcus sp., Neisseria sp, Bacteroides sp, Actinomyces sp, Treponema sp, Mycoplasma sp. ${ }^{19}$ These microorganisms can colonize the oral cavity, and also the environment where the toothbrushes are stored. ${ }^{21}$ In addition, organisms normally associated with the oral flora have been isolated from toothbrushes, including the family Enterobacteriaceae ${ }^{20}$ and its origin is probably the bathroom. ${ }^{21}$ The toothbrush should be sanitized or disinfected and replaced in regular time periods. In this context, studies of microbial contamination of toothbrushes in vivo, proposing methods for its sanitation or disinfection, ${ }^{3}$ have emerged over the last two decades Many consumers buy less than a toothbrush for year despite recommendations made by dentists, where a toothbrush must be used for a maximum period of three months. The brushes can become less effective for removing plaque compared with a new toothbrush, yet consumers are usually reluctant to replace the brushes more frequently. ${ }^{3,24}$ This present study aimed to evaluate the microbiological contamination of toothbrush bristles in continuous use, using two different methods.

\section{MATERIALS AND METHODS Sample collection}

The samples were randomly collected from apparently healthy individuals. The inclusion criteria were: 1) free age, 2) used the toothbrush at least three times a day; 3 ) the duration of use was over a month. Were excluded from the study subjects who had one or more of the following criteria: 1) bleeding gums and mouth, 2) dental post surgery 3 ) hospitalized subjects. The number of samples used comprised of 40 frequently used toothbrushes. The average use of toothbrushes in four participants was 3 months, in 9 participants was 5 months of use, in seven subjects was 1 month and 20 participants was 7 months of use. These brushes were collected aseptically in a sterile container and send immediately to the microbiology laboratory at the University of the Extreme South of Santa Catarina for microbiological analysis of the bristles.

\section{Microbiological processing}

For the analysis two different methodologies were used. The first method was developed by Cleri, Corrado and Seligman ${ }^{5}: 20$ toothbrushes were placed in test tubes containing $5 \mathrm{~mL}$ of tryptic soy broth (TSB). Sterile tubes were homogenized three times added 10.1 $\mu l$ loop and plated on sheep blood agar containing $5 \%$ and MacConkey agar. The plates were stored in a bacteriological incubator at $37^{\circ} \mathrm{C}$ for a 24 hours period for microbial growth analysis. The second method was developed by Sherertz, Raad and Balani ${ }^{22}: 20$ toothbrushes were placed individually in a test tube containing $5 \mathrm{~mL}$ of tryptic soy broth (TSB), then the samples were homogenized for $15 \mathrm{~s}$ with vortex. The brushes were removed from the culture medium and passed through $0.05 \mathrm{~mL}$ to $5 \mathrm{~mL}$ of sterile TSB broth with a micropipette, resulting in a dilution of 1:100. 
This broth was homogenized again and with addition of a $0.1 \mathrm{~mL}$ loop was streaked on plates containing sheep blood agar and 5\% MacConkey agar. The plates were stored in a bacteriological incubator at $37^{\circ} \mathrm{C}$ for a period of 24 hours for microbial growth analysis. After $24 \mathrm{~h}$ growth the colony-forming units (CFU) were counted and subsequent microorganisms identification. For the microorganisms identification was performed Gram stain and biochemical tests.

\section{RESULTS}

According to the methodology of Cleri, Corrado and Seligman, ${ }^{5}$ in the present study the results showed that there was contamination in 14 samples totaling $70 \%$. In the remaining $30 \%$ there was no microbial growth. The bacteria identified in the seeded culture media growth were Escherichia coli with $45 \%$, followed by Klebsiella pneumoniae $35 \%$, Streptococcus pyogenes and Staphylococcus coagulase negative with $10 \%$, as shown in Table 1. Table 2 shows the frequency of colony-forming units (CFU), in which $30 \%$ of samples were considered negative and there were no growth in plates containing culture media. Moreover, $25 \%$ of the sample had an average of $220500 \mathrm{CFU} / \mathrm{mL}, 20 \% 367500$ $\mathrm{CFU} / \mathrm{mL}, 15 \% 514500 \mathrm{CFU} / \mathrm{mL}$ and $10 \% 661500$ $\mathrm{CFU} / \mathrm{mL}$ totaling $70 \%$ with microbial growth. In Figure 1, it is seen an exponential growth in the number of bacteria related to the time of toothbrushes use, and increased toothbrushes contamination in accordance with its longer usage. In the second method mentioned by Sherertz, Raad and Balani, ${ }^{22}$ was detected microbial growth in just five toothbrushes totaling $25 \%$ of the samples and on 15 brushes the result was an absence of growth in total percentage of $75 \%$. Table 3 shows the microorganisms found, Escherichia coli in $80 \%$ brushes and Klebsiella pneumoniae in $20 \%$ and the average colony-forming units (CFU) was $126555 \mathrm{CFU} / \mathrm{mL}$, and the brushes usage time was on average 5 months.

\section{DISCUSSION}

The toothbrushes contamination can play an important role in the development of various diseases. Brushes should be replaced monthly and should not be stored in closed or wet containers, these locations associated with the substrate food scraps facilitate
Table 1 - Frequency of microorganisms found using the method of Cleri, Corrado and Seligman ${ }^{5}$.

\begin{tabular}{cc|}
\hline Bacteria & Percentage \\
\hline Escherichia coli & $45 \%$ \\
Klebsiella pneumoniae & $35 \%$ \\
Streptococcus pyogenes & $10 \%$ \\
Staphylococcus coagulase negative & $10 \%$ \\
\hline
\end{tabular}

Table 2 - Frequency of CFU/mL in toothbrushes.

\begin{tabular}{ccccc}
\hline \multicolumn{2}{c}{ Class } & Midpoint & $\begin{array}{c}\text { Absolute } \\
\text { frequency }\end{array}$ & $\begin{array}{c}\text { Relative } \\
\text { frequency }\end{array}$ \\
\hline 0 & 147000 & 73500 & 6 & $30 \%$ \\
147000 & 294000 & 220500 & 5 & $25 \%$ \\
294000 & 441000 & 367500 & 4 & $20 \%$ \\
441000 & 588000 & 514500 & 3 & $15 \%$ \\
588000 & 735000 & 661500 & 2 & $10 \%$ \\
\hline
\end{tabular}

Table 3 - Frequency of microorganisms found using the method Sherertz, Raad and Balani ${ }^{22}$ (1990).

\begin{tabular}{cc} 
Bacteria & Percentage \\
\hline Escherichia coli & $80 \%$ \\
Klebsiella pneumoniae & $20 \%$ \\
\hline
\end{tabular}

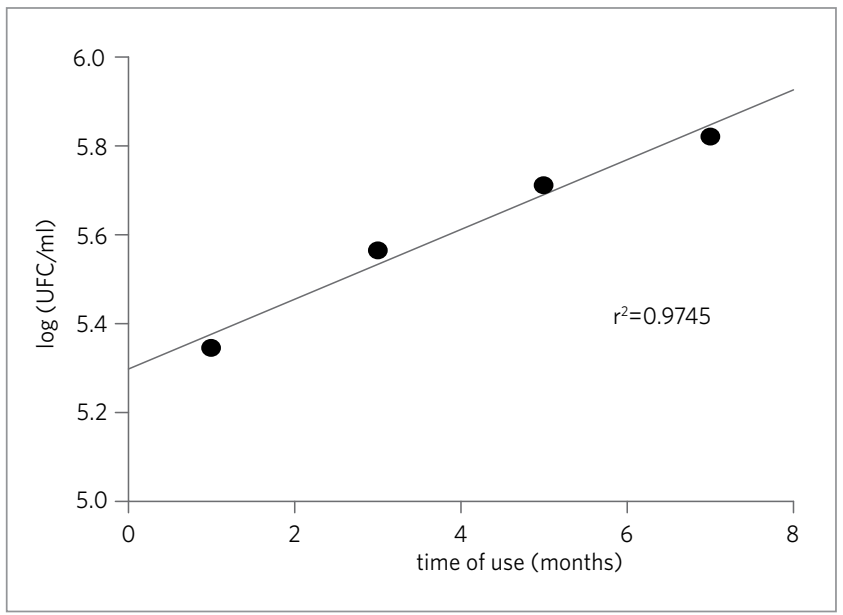

Figure 1 - Relation of bacterial growth medium ( $\log (\mathrm{CFU} / \mathrm{mL}))$ using the method of Cleri, Corrado and Seligman ${ }^{5}$, and the time of use of toothbrushes $(n=20)$

the microorganisms growth., ${ }^{711}$ The second method by Cleri, Corrado and Seligman, ${ }^{5}$ was suitable for studying microorganisms in toothbrushes. In this method, no dilution was performed to facilitate the growth and identification of contaminating microorganisms.

Taji and Rogers, ${ }^{23}$ in their studies with toothbrushes, assessing contamination of utensils, identified the growth of Staphylococcus sp, Streptococcus, 
Aerococcus sp, Pseudomonas sp, fecal coliform, among others. Toothbrushes can be a growth site for Streptococcus pyogenes and this microorganism is responsible for pharyngitis in children. ${ }^{2}$ A study conducted by Moreira and Cavalcante ${ }^{16}$ reported that $100 \%$ of contaminated brushes were positive for four species of microorganisms: Candida albicans, Escherichia coli, Streptococcus mutans and Bacillus subtilis. In our results $81 \%$ and $100 \%$ of the microorganisms identified in both methodologies were members of the family Enterobacteriaceae. Toothbrushes are usually stored in the toilets and exposed to contamination, since it is a microbial environment with the presence of mainly enteric bacteria spread by aerosols from the toilet. ${ }^{23}$ A study of Long and Santos ${ }^{14}$ indicated that none of the brushes that are kept inside the bathroom cabinet showed a growth of enterobacteria, whereas the degree of contamination with the presence of two major sorts of fecal coliforms (Enterobacter sp and Citrobacter sp) in brushes kept on the bathroom sink was $70 \%$. The cabinet seems to be the safest place in the bathroom to prevent bristles contamination.

In previous studies we examined the toothbrushes time of use for each subject: $17.5 \%$ reported that they change their toothbrush every 30 days, $32.5 \%$ every six months and $50 \%$ of participants reported that only replace brush once a year. In this work, we found that the brush exchange is essential for good oral hygiene, since the longer is the use, the greater is the wear and microorganisms accumulation in the bristles. The presence of these organisms can be related to the lack of cleaning in the bristles or the brushes storage in wrong places with high rates of heat and humidity, which facilitates the spread and growth of these microorganisms. Among the survey members we found that $90 \%$ store the brushes in the bathrooms and among them $30 \%$ placed in lockers and $60 \%$ reported that the brushes are stored in a location such as exposed in the bathroom, over the sink, counter, glasses, among others. Regarding the use of protective cover on the brush, $90 \%$ of respondents did not use the cover protection on their brushes. The average number of persons using the bathroom was 3 per household, and 97.5\% did not have habit of lowering the toilet lid to flush. Regarding the frequency of visits to the dentist,
7.5\% reported visiting once a month, $15 \%$ every 6 months, $77.5 \%$ once a year and $97.5 \%$ reported that they never received instructions on how to properly store the toothbrush.

Grigoletto $^{12}$ and colleagues stated in their studies that the ideal use rate of toothbrushes is four per year, or one every three months. Study conducted in Brazil in 1997 showed that half of the population (about 85 million people) had no toothbrush and the per capita toothbrush consumption was considered low. Brazilians usually buy a brush every 17 months but the recommendation of the oral health society is to change the toothbrush every three months and every three days for patients undergoing chemotherapy. ${ }^{2}$ According to Barros, Pernambuco and Tomital the brush should be kept clean without waste (food or toothpaste) and should be stored where it can dry and without direct contact with other brushes. According to the literature, there are some controversies regarding the storage of the brushes in the bathroom cabinets. Meier ${ }^{15}$ and colleagues reported that the bathroom cabinet, boxes and bristles protectors are not the most appropriate location for the storage of toothbrushes, this is justified by the fact that those places maintain a moist environment and warm around the bristles and it may promote the microbial growth. Caudry and Klitorinos ${ }^{3}$ and Coutinho ${ }^{6}$ et al mentioned that the bathroom cabinet can favor the occurrence of cross-contamination, because the brushes are often stored with their heads in contact with other microorganisms that can pass to each other pathogens also related to respiratory infections, intestinal and other diseases. Brushes should be washed with running water and the water excess must be removed by tapping the edge on the sink and never dry in a towel, then you should spray on the bristles with mouthwash and store it in an open and airy place. ${ }^{16}$ There are already some studies on the toothbrushes disinfection, Chaves ${ }^{4}$ and colleagues (2007), reported that the decontamination process of brushes must have a longer range, including the poorest populations and should be evaluated by disinfection methods that are effective and easy to perform, such as the use of sodium hypochlorite $1 \%$ and $0.05 \%$ acetic acid. Good oral hygiene habits are common when oral health values are accepted as part of the family lifestyle, 
and historically, women are more involved in this process. The mothers' example is crucial for their children to acquire good habits. ${ }^{8}$

\section{CONCLUSION}

According to the results presented in this study, we observed a high incidence of bacterial contamination in the analyzed brushes. The microorganisms more frequently found were members of the Enterobacteriaceae family. The toothbrushes time of use can be related to contamination found and therefore not only a good cleaning will ensure the reduction of microbial load, but the toothbrush exchange can also ensure better oral health to individuals.

\section{REFERENCES}

1. Barros OB, Pernambuco R, Tomita N. Escovas dentais. Pós-Grad Rev Fac Odontol. 2001; 4:33-8

2. Bhat SS, Hegde KS, George RM. Microbial contamination of tooth brushes and their decontamination. J Indian Soc Pedod Prev Dent. 2003 Sep;21(3):108-12.

3. Caudry SD, Klitorinos A, Chan EC. Contaminated toothbrushes and thei disinfection. J Can Dent Assoc. 1995 Jun;61(6):511-6.

4. Chaves RAC, Ribeiro DML, Zaia JE, Alves EG, Souza MGM, Martins CHG. Avaliação de soluções antibacterianas na descontaminação de escovas dentais de pré-escolares. Rev Odont UNESP. 2007;36:29-33.

5. Cleri DJ, Corrado ML, Seligman SJ. Quantitative culture of intravenous catheters and other intravascular inserts. J Infect Dis. 1980 Jun;141(6):781-6.

6. Coutinho PG, Bittar P, Ditterich RG, Rastelli MC, Romanelli MCMOV, Wambier D. Stadler Evaluation of the storage and preservation means of toothbrushes used by preschool. Rev Odonto Ciênc. 2007 Out-Dez;22(58):335-9.

7. Dayoub MB, Rusilko D, Gross A. Microbial contamination of toothbrushes. J Dent Res. 1977 Jun;56(6):706

8. Faustino-Silva D, Ritter F, Nascimento IM, Fontaine PVN, Persici S, Rossoni E. Cuidados em saúde bucal na primeira infância: percepções e conhecimentos de pais ou responsáveis de crianças em um centro de saúde de Porto Alegre, RS. Rev Odonto Ciênc. 2008;23:375-9.

9. Figueiredo MC, Faustino-Silva DD. Efetividade da dedeira de gaze comparada à escova dental convencional no controle do biofilme dentário em bebês. ConScientiae Saúde. 2008;7:357-66.

10. Fratto G, Nazzicone M, Ortolani E. Disinfezione degli spazzolini dentali. Ricerca sperimentale. PrevAssist Dent. 1990;16:7-10.

11. Glass RT, Lare MM. Toothbrush contamination: a potential health risk? Quintessence Int. 1986 Jan;17(1):39-42.

12. Grigoletto JC, Watanabe MGC, Mestriner Junior W, Bregagnolo J. Higiene oral e uso compartilhado de escova dental. Rev Odont UNESP. 2006;35(2):175-81.
13. Kozai K, Iwai T, Miura K. Residual contamination of toothbrusher by microorganisms. ASDC J Dent Child. 1989 May-Jun;56(3):201-4.

14. Long SR, Santos AS, Nascimento CMO. Avaliação da contaminação de escovas dentais por enterobactérias. Rev Odontol Univ St Amaro. 2000;5:21-5.

15. Meier S, Collier C, Scaletta MG, Stephens J, Kimbrough R, Kettering JD. An in vitro investigation of the efficacy of CPC for use in toothbrushes decontamination. J Dent Hyg. 1996 Jul-Aug;70(4):161-5.

16. Moreira ACS, Cavalcante GM. Influência da higienização na contaminação de escovas dentais. Arq Ciênc Saúde Unipar. 2008;12: 99-103.

17. Panzeri H, Lara EHG, Zaniquelli O, Schiavetto F. Avaliação de algumas características das escovas dentais do mercado nacional. Rev. ABO Nac. 1993:1(1):23-9.

18. Paschoal AD, Rotta JCP. Conservação e uso das escovas. RGO- Rev Gaúcha Odont 1992;40:276-8.

19. Porto SMMS, Viana MT, Silva KMF, Diniz MFA, Castro CMMB. Neonatal malnutrition and normal microbiota of the oral cavity in rats. Rev Nutr. 2007;20(6):625-32.

20. Sammons RL, Kaur D, Neal P. Bacterial survival and biofilm formation on conventional and antibacterial toothbrushes. Biofilms. 2004;1: 123-30.

21. Sato S, Ito IY, Lara EH, Panzeri H, Albuquerque Junior RF, Pedrazzi V. Bacterial survival rate on toothbrushes and their decontamination with antimicrobial solutions. J Appl Oral Sci. 2004 Jun;12(2):99-103.

22. Sherertz RJ, Raad II, Belani A, Koo LC, Rand KH, Pickett DL, et al. Three-year experience with sonicated vascular catheter cultures in a clinical microbiology laboratory. J Clin Microbiol. 1990 Jan;28(1):76-82

23. Taji SS, Rogers AH. The microbial contamination of toothbrushes. A pilot study. Aust Dent J. 1998 Apr;43(2):128-30.

24. Tan E, Daly C. Comparison of new and 3-month-old toothbrushes in plaque removal. J Clin Periodontol. 2002 Jul;29(7):645-50. 